Kilis 7 Aralık Üniversitesi Sosyal Bilimler Dergisi Kilis 7 Aralık University Journal of Social Sciences ISSN 2146-4561

Haziran/June 2020, 10 (19):127-149

Sınıf Öğretmenlerinin Okul Gürültüsüne İlişskin Görüşleri Primary School Teachers' Opinions on School Noise

Aslıhan KENBER ÇİTÇi

Öğretmen, Milli Eğitim Bakanlığı, Efeler, AYDIN

e-posta: a.k.ciftci@hotmail.com

ORCID: http://orcid.org/0000-0002-7346-1663

\title{
Bilgen KIRAL
}

Doç. Dr., Aydın Adnan Menderes Üniversitesi, Efeler, AYDIN e-posta: bilgen.kiral@adu.edu.tr

ORCID: http://orcid.org/0000-0001-5352-8552

\section{Makale Bilgisi/Article Information}

Makale Türü/Article types: Araştırma Makalesi/Research Article Geliş Tarihi/Received: 6 Nisan 2020/ 6 April 2020

Kabul Tarihi/Accepted: 6 Haziran 2020/ 6 June 2020

Yayın Sezonu/Pub Date Season: Haziran 2020/ June 2020

Atıf/Cite as: Kenber Çiftçi, Aslıhan ve Kıral, Bilgen (2020), Sınıf Öğretmenlerinin Okul Gürültüsüne İlişkin Görüşleri/Primary School Teachers' Opinions on School Noise, Kilis Üniversitesi Sosyal Bilimler Dergisi, 10 (19), 127-149, doi:https://doi.org/10.31834/kilissbd.715338

\section{Rights reserved.}

For Permissions

sbedergi@kilis.edu.tr 


\title{
SINIF ÖĞRETMENLERININ OKUL GÜRÜLTÜSÜNE ILISSSKIN GÖRÜŞLERi ${ }^{1}$
}

\section{ÖZ}

Çalışma, ilkokullarda görev yapan sınıf öğretmenlerinin gürültü ve kaynaklarını ve bunun üzerlerindeki etkilerini araştırmak amacıyla yapılmıştır. Araştırma, nitel araştırma desenlerinden fenomenoloji kullanılarak yürütülmüş olup; 2018-2019 akademik yılında Aydın ilinde çalışmaya katılmaya gönüllü olan 10 sınıf öğretmeni ile gerçekleştirilmiştir. Araştırmaya katılan öğretmenler seçilirken; amaçlı örnekleme yöntemlerinden kolay ulaşılabilir, ölçüt örneklem ve maksimum çeşitlilik örnekleme yöntemleri kullanılmıştır. Araştırmada veriler görüşme yöntemi kullanılarak toplanmıştır. Veri toplama aracı olarak sınıf öğretmenlerine yönelik hazırlanan ve sekiz sorudan oluşan yarı yapılandırılmış görüşme formu kullanılmıştır. Araştırma sonuçlarına göre gürültünün düzeyi çok yüksek olup; gürültü kaynağının özellikle öğrenciler olduğu katılımcılar tarafından ifade edilmiştir. Genel olarak gürültü; teneffüs saatlerinde, koridorlarda yoğun olarak yaşanmaktadır. Öğretmenler gürültü karşısında sözel ikazlarda bulunmaktadırlar. Öğretmenlerin gürültüden psikolojik, bedensel ve ailevi açılardan etkilendiği sonucu ortaya çıkmıştır. Okul yöneticilerinin gürültüyü azaltmak amacıyla yaptıkları önemli bir çalışma olmadığ 1 tespit edilmiştir. Öğretmenlerin gürültüyü azaltmak amacıyla; okul binalarının fiziki koşullarının iyileştirilmesi, gürültü konusunda öğrencilerin ikaz edilmesi ve enerjilerini boşaltacak aktivitelere yönlendirilmesi, ders saatlerinde değişiklik yapılarak sabah saatlerinde akademik çalışmaların, son saatlerde ise bedensel aktivite ya da sosyal etkinliklerin planlanması, aileler ile eğitim programlarının düzenlenmesi gibi önerilerde bulunmuşlardır.

Anahtar Sözcükler: İlkokul, Sınıf öğretmeni, Gürültü, Okul gürültüsü, Etki

\section{PRIMARY SCHOOL TEACHERS' OPINIONS ON SCHOOL NOISE}

\begin{abstract}
This study was conducted to research effects of noise on individuals and the sources of it according to primary school teachers. The research was carried out by using phenomenology which is one of the qualitative research designs. 10 volunteer primary school teachers in province at 2018-2019 academic year took part in the study. While selecting the teachers participating in the research, purposive sampling methods convenient sampling, criterion sampling and maximum variation sampling methods was used. Data was collected by interview method. Semi-structured interview form was used to collect data consisting eight questions prepared for
\end{abstract}

\footnotetext{
${ }^{1}$ Bu çalışma 1.yazarın Doç. Dr. Bilgen KIRAL danışmanlığındaki tezsiz yüksek lisans projesinden üretilmiştir.
} 
primary school teachers. According the results, it was stated by participants, level of noise in schools is very high and the source of it is especially students. Usually noise is experienced intensely in the school corridors during breaks and teachers give verbal warning against to them. It has been concluded that teachers are affected from noise in psychological, physical and family. It has been determined that there is no significant study conducted by the school administrators to reduce noise pollution. In order to reduce the noise; teachers' advice improvement of the physical conditions of school buildings, warning students about noise and directing them to activities that will discharge their energy, making changes in course hours like academic studies in the morning, physical activities or social activities in the last hours, and organizing educational programs with families. Affect

Keywords: Primary School, Primary School Teacher, Noise, School Noise,

\section{GİRİŞ}

İnsanoğlu hayatını sürdürebilmek için toplum içinde yaşamaya mecburdur. Toplumsal yaşam biçiminin; insan hayatına kolaylıklar sağlayan unsurlar içermesinin yanı sıra, insan hayatını güçleştiren tarafları da bulunabilmektedir. Toplumsal yaşama biçimi ile birlikte, giderek artan ihtiyaçlar, insanların çok ileri teknolojiler keşfetmelerine yol açmıştır. Bu da insanların çeşitli ses kaynaklarıyla bir arada kalmalarına sebep olmaktadır. Bunun doğal bir sonucu olarak da gereğinden fazla teknolojik sesin bir arada olmas1 gürültüye sebep olmakta; bu da insanları ve insanların bir arada olduğu örgütsel ve toplumsal yaşamı etkilemekte, bireylerde stres oluşturarak iş ve yaşam kalitesini düşürebilmektedir (Kıral, 2016).

Toplumsal yaşamın bir parçası olan okullar, en küçük birimi insan olan örgütlerdir. İnsana doğrudan ya da dolaylı olarak etki eden her şey okul iklimini (Işık, 2015: 69), öğrenci başarısını ve öğretmen performansını olumlu ya da olumsuz olarak etkileyebilmektedir (Adigüzel, 2011). Bu unsurların en önemlilerinden birisi olarak gürültü sayılabilir. Yapılan araştırmada öncelikle gürültü kavramı, gürültünün birey üzerindeki etkileri, okul ortamında gürültü incelenmiş, ardından öğretmen görüşleri doğrultusunda okulda gürültüue ilişkin elde edilen bulgular açıklanmıştır.

\subsection{Gürültü ve Etkileri}

Gürültü, teknolojide meydana gelen gelişmeler ve insanların yaşam biçiminde oluşan değişiklikler sonucu negatif fizyolojik ve mental etkiler oluşturan istenmeyen sesler olarak tanımlanabilir (Maraş, Maraş, Maraş ve Alkış, 2011: 52). Gürültünün çeşitli kaynakları bulunmaktadır. Güney (1998) gürültü kaynaklarını, insan davranışlarından kaynaklanan ve kaçınılmaz olan gürültüler olarak ikiye ayırmaktadır. İnsan davranışlarından dolayı olanlar, 
yüksek sesle konuşmak, bağırmak, şarkı söylemek, koşmak, müzik dinlemek olarak çeşitlendirilebilir. Kaçınılmaz gürültüler ise kara, deniz ve hava yolu trafiği, inşaat işleri olarak örneklendirilebilir (Alpteker, 2018: 109).

Gürültünün meydana gelebilmesi için sesin kulağa gelmesi gerekmektedir. Gürültü seviyesi desibel (dB) ile ölçülür ve $80 \mathrm{~dB}$ üzerindeki gürültü kalıcı sağlık sorunları oluşturabilir (Hayta, 2007: 29). Buna ilişkin Tablo 1'de farklı gürültü aralıklarının insanı nasıl etkilediği verilmiştir (Polat ve Buluş-Kırıkkaya, 2004: 3).

Tablo 1: Gürültü Aralıkları ve Etkileri

\begin{tabular}{|c|c|}
\hline $\begin{array}{l}\text { Gürültü } \\
\text { Seviyesi }\end{array}$ & Gürültü Etkisi \\
\hline $0-35 \mathrm{~dB}$ & Zarar vermeyen gürültü \\
\hline $36-65 \mathrm{~dB}$ & Uyku ve dinlenmeyi bozabilen rahatsız edici gürültü \\
\hline 66-85 dB & $\begin{array}{l}\text { Rahatsız edici ruhsal yönden zarar veren kulak sorunlarına yol açan } \\
\text { gürülttü }\end{array}$ \\
\hline $86-115$ dB & $\begin{array}{l}\text { Ruhsal ve fiziksel yönden zarar veren psikosomatik rahatsızlıklara yol } \\
\text { açan gürültüi }\end{array}$ \\
\hline 116-130 dB & $\begin{array}{l}\text { Tehlikeli gürültü, sağırlık ve buna benzer önemli rahatsızlıklara yol } \\
\text { açan gürültüi }\end{array}$ \\
\hline 131-150 dB & Çok tehlikeli anında önemli hasar oluşturan gürültü \\
\hline
\end{tabular}

Tablo 1'e göre zarar vermeyen gürültü seviyesi 0-35 dB aras1 olarak tespit edilmiştir. 36-65 dB arası gürültü, uyku ve dinlenmeyi bozacak şekilde rahatsız eden gürültü seviyesini, $66-85 \mathrm{~dB}$ arası kulak rahatsızlığına neden olabilen gürültü seviyesini oluştururken; 86-115 $\mathrm{dB}$ aras1 gürültü psikosomatik rahatsızlıklara neden olmakta; $116-130 \mathrm{~dB}$ arası sağırlığa neden olabilecek seviye olarak belirtilmiştir. $130 \mathrm{~dB}$ üstü gürültü ise çok tehlikeli ve kısa zamanda önemli rahatsızlıklara neden olabilecek gürültü seviyesi olarak belirtilmiştir.

\subsection{Gürültünün Fiziksel Etkileri}

Gürültünün seviyesine bağlı olarak vücutta bazı değişiklikler ve hasarlar meydana gelebilmektedir. Yüksek gürülttü düzeylerinde sürekli işitme kaybı gibi önemli sıkıntılarla karşılaşılabilmektedir. Gürültü düzeyindeki artış, kişilerde erken yaşlarda sağırlık ve kulak çınlamaları gibi rahatsızlıklar da ortaya çıkarabilmektedir. Gürültünün hipertansiyon, çarpıntı, adrenalin ve kolesterol seviyesinde yükselme, solunum hızında artış, sindirim sisteminde düzensizlik, uyku bozukluğu gibi rahatsızlıklara neden olmasının yanı sira stres ve stres kaynaklı hastalıklara da yol açmaktadır (Kıral, 2016: 11). 


\subsection{Gürültüinün Psikolojik Etkileri}

Yüksek düzeyde gürültüye maruz kalmış kişilerin birçoğunun motivasyon ve verimliliğinde düşüş yaşandığı (Kıral, 2016: 11), ayrıca çeşitli psikolojik etkiler gözlendiği ve çevresel gürültülerin insanların ruh hastalıklarını hızlandırdığı ve artırdığı gözlemlenmiştir. Gürültü ile stres; var olan duygusal düzensizliği daha da artırmaktadır. $\mathrm{Bu}$; gürültünün yüksekliğine, gürültü kaynağının belirsiz oluşuna ve gerilim oluşturmasının yüksek seviyede oluşuna göre birtakım davranış bozuklukları şeklinde olabilmektedir. Bu bozukluklar; ani parlama, öfke, kendini kaybetme, şiddete meyletme, kendini suçlama, aşırı sessiz kalma, tartışmacı bir karaktere bürünme, sakinleştirici ilaç kullanma, sosyal iletişimde hoşgörünün azalması, sık s1k hastalanma olarak sayılabilir (Şan, 2010).

\subsection{Gürültünün Performans Üzerindeki Etkileri}

Kişilerin iş verimlerinin gürültüden ne şekilde etkilendiği araştırılmış ve sonuçlar şu şekilde ortaya konulmuştur: Okullarda gerek öğrenci gerekse öğretmenlerin okuma ve anlama oranlarının, sosyal ilişkilerin ve karşılıklı konuşmaların, yapılan işin kalitesinin ve yapılma hızının, dikkat toplamanın ve toparlanan dikkatin süresinin, iş performansı ve veriminin gürültüden olumsuz yönde etkilendiği yapılan bazı araştırmalar (Bulunuz ve Güner, 2017; Evans, Hygge ve Bullinger, 1995; Evans ve Maxwell,1997 gibi) ile tespit edilmiş olup; bunun dışında karayolları, havaalanları ve demiryollarına yakın mesafelerdeki okullarda eğitim gören öğrencilerin okuma-anlama, derse ilgi ve öğrenme seviyelerinde gerileme yaşandığ da tespit edilmiştir (Şan, 2010: 39).

\subsection{Okul Ortamında Gürülttü}

Okullarda eğitimin kaliteli bir biçimde yapılabilmesi, ögretmen ve öğrencilerin birbirleriyle rahatça iletişim kurmaları için içerisinde bulundukları çevrenin akustiğinin buna imkân vermesi gerekmektedir. Gürültü ise öğretmen ve öğrencilerin sağlığını etkileyen, rahatsızlık veren, onların gelişimini etkileyen ve sınıf içerisinde iletişimin kalitesinin bozulmasına neden olan önemli bir çevre kirliliği problemidir (Özbıçakçı vd., 2012: 240).

Okullardaki gürültünün genel anlamda iki kaynağı bulunmaktadır. Bunlardan ilki; kapalı okulda yapılan taşıma, delme, vurma, çakma gibi okul binasına ilişkin işler ile öğrenci sesleri, ikincisi ise; okul dışından kaynaklanan gürültüler olarak sayılabilir. Gürültü, öğrenmeyi olumsuz etkilemektedir. Derslerde, öğretmen ve öğrencilerin dikkatlerini dağıtmakta; zihinsel olarak yorulmaya ve öğrenmeyi güçleştirmeye neden olmaktadır. Sinıfta öğrenmenin oluşabilmesi için gürültü düzeyi değerinin, belirlenen 
sınırlar içerisinde olması gereklidir (Bulunuz ve Güner, 2017). Çünkü gürültülü bir ortam, öğrencilerin dikkatini dağıtmakta ve sıkılmalarına yol açmaktadır (Akbaba ve Turhan, 2016). Işık'a (2004) göre sınıf içinde ses emici yüzeyler oluşturma, yerlerin halıyla kaplanması, gerekiyorsa ses düzeneklerinin oluşturulması, havalandırma ve klima gibi araçların seçimi ve kullanımı konusunda dikkatli olunması gürültünün en aza indirilmesinde etkili olabilir.

Son yıllarda gürültünün öğrencilerin öğrenmesi ve okul başarısı üzerindeki etkilerini ve gürültüden rahatsız olma düzeylerini araştırmaya yönelik bir takım çalışmalar ortaya konmuştur. Schick, Klatte ve Meis (2000) yaptıkları çalışmada, evlerindeki gürültüsüz ortamdan çıkıp, gürültülü sınıflarda eğitim gören çocukların, yapılan sınavlarda gürültüsüz sınıflardaki öğrencilerden daha başarısız olduklarını tespit etmişlerdir. Ayrıca Shield ve Dockrell (2004), Londra'da 142 okulda yaptıkları çalışmalarda, arka plan gürültüsünün standart aralıkların üstünde ve sınıfın akustik durumunun bozuk olmasının, öğrencilerin anlama ve konsantrasyon sorunu yaşamalarına sebep olarak bulmuşlardır. $\mathrm{Bu}$ araştırmaların sonucunda genellikle ögrencilerin dikkat ve akılda kalma ile ilgili ya da okuduğunu kavrama ve yapılan sınavlarda, akademik başarıları üzerinde olumsuz etkisi olduğu ortaya konulmuştur.

Picard ve Bradley (2001) tarafindan, Kanada'nın Quebec bölgesinde üç okulda yapılan araştırmada okullardaki gürültü düzeyi 40 ile $70 \mathrm{~dB}$ arasında ölçülmüştür. Dünya Sağl1k Örgütü ve Amerika'da öğrenme için ideal değer $35 \mathrm{~dB}$ olup, araştırmada ölçülen değerler, belirlenmiş olan standardın çok üstünde çıkmıştır. Araştırmacılar, ilköğretim okulu yıllarında matematik ve okuma parçalarının öğrenilmesini özellikle araştırmış ve yaptığı çalışma ile verimli öğrenme ortamı ile sınıftaki gürültü düzeyi arasında doğrudan ilişki tespit etmişlerdir (Akt. Güremen, 2012).

Gürültünün eğitime yansımalarını değerlendiren araştırmacılardan Maxwell ve Evans (2000), yüksek gürültüye maruz kalan okul öncesi çocuklarıyla, akustik olarak yalıtılmış bir ortamda eğitim gören çocukların erken dönem okur-yazarlık becerilerini karşılaştırmışlardır. Bir yıl süren bu çalışmanın sonucunda, daha az gürültüye maruz kalan çocukların, erken dönemdeki okur-yazarlık becerilerinin, diğer çocuklara göre daha yüksek olduğu tespit edilmiştir.

Gürültünün öğrenme süreçleri üzerindeki etkisini değerlendiren araştırmalardaki diğer bir bulgu ise yaş ve gürültü arasındaki ilişkidir. Üçüncü ve dördüncü sınıftan itibaren gürültünün öğrenme üzerinde daha az etkiye sahip olduğu ve dördüncü sinıftan itibaren öğrencilerin gürültüyü daha iyi kontrol edebildikleridir (Imhof, Henning ve Kreft, 2009). 
Güremen'in (2012) yaptığ1 çalışmada ortaya koyduğu ilköğretim okullarındaki gürültü seviyelerinin oldukça yüksek olması, erken yaşlarda öğrencilerin akademik becerileri edinirken zorlanabileceklerini göstermektedir. Stansfeld vd. (2005) yaptıkları çalışmada, gürültünün eğitim üzerindeki olumsuz etkilerini incelemiş, okul dışındaki gürültünün uzun süreli belleği, okuma ve anlamayı, dikkati ve okula devam durumunu olumsuz etkilediğini bulmuşlardır. Tüzel (2013) sınıf içi gürültü seviyelerinin, öğrencilerin anlama ve hatırlamaları üzerindeki etkilerini araştırmıştır. Araştırmasında 146 kişilik katılımcı grubunu ikiye ayırmış; birine gürültülü sınıf ortamında (79 $\mathrm{dBA})$ diğerine ise ses yalıtımı yapılmış sınıf ortamında (36 dBA) okuma metni dinletmiş̧tir. Bunun sonucunda, ses yalıtımı yapılmış ortamda metni dinleyen öğrencilerin anlama ve hatırlama becerilerinin daha iyi olduğunu tespit etmiştir.

Okullar için öngörülen en yüksek ses düzey 35-45 dB' dir. Sınıf içi sesleri azaltmanın en iyi yolu okulun ilk günlerinden itibaren gürültü düzeyinin belirlenip, gerekli önlemlerin uygulanmasıdır. Türkiye'de uygulanmakta olan yönetmeliklerde kabul edilebilir gürültü düzeyi $45 \mathrm{~dB}$ olarak öngörülmektedir (Özbıçakçı vd., 2012: 240). Verimli bir öğretim ve öğrenme isteniyorsa, sınıftaki gürültü düzeyinin belli standartlar arasında kalması lazımdır. Gürültü düzeyinin belirlenmiş olan standartları aşması sonucunda algının azalması, dikkatin dağılması, okuduğunu anlama süresinin uzaması, öğrencilerde agresif hareketlerin artması ve derse ilginin azalması, gürültüden dolayı öğretmenlerin erken yorulması gibi istenmeyen durumların oluşması ortaya çıkacaktır. Bu da eğitimin kalitesini olumsuz olarak etkileyecektir (Avşar ve Gönüllü, 2000: 987).

Alan yazında da okul gürültüsüne yönelik çeşitli çalışmalar (Adıgüzel, 2011; Bulunuz ve Güner, 2017; Evans, Hygge ve Bullinger, 1995; Evans ve Maxwell 1997; Güremen, 2012; Polat ve Buluş-Kırıkkaya, 2004; Stansfeld vd. 2005; Şahin, Şahin ve Bağc1, 2014; Şan, 2010; Tuncer, Bal, Özüt ve Köse, 2012) yapıldığı görülmektedir. Bu çalışmalardan hareketle; okul gürültüsünün sınıf öğretmenlerinin hayatlarını hangi alanlarda ve ne şekilde etkilediğinin ortaya çıkarılması ve bu konuda ilgili okul birimlerinin, ilgili kurum ve kuruluşlar ile kişilerin alabilecekleri önlemlerin tespiti konusunda önemli bir adım olarak kabul edilebilir. Yapılan bu araştırma ile gerek toplumsal hayata gerekse eğitim sistemine yön veren eğitim kurumlarından biri olan ilkokullarda çalışan sınıf öğretmenlerinin; görev saatleri süresince maruz kaldıkları gürültü, bu gürültüden nasıl etkilendikleri, gürültünün kişisel hayatlarına olan etkilerinin tespiti, eğitim çevreleri ve ilgililere bu sorunun çözümü olarak gördükleri önerilerin iletilmesi ve gerekli tedbirlerin alınması bakımından büyük önem taşımaktadır. 


\subsection{Araştırmanın Amacı}

$\mathrm{Bu}$ çalışma ile Aydın ilinde bulunan ilkokullardaki sınıf öğretmenlerinin okul gürültüsü ile ilgili görüşlerini tespit etmek amaçlanmıştır. Bu temel amaçtan yola çıkarak, okul ortamındaki gürültünün kaynaklarına, etkilerine ve kontrol edilmesiyle ilgili yapılması gerekenlerin neler olduğuna ilişkin sorulara cevaplar aranmış, bu sorularla ilgili öğretmenlerin görüşlerinin neler olduğu tespit edilmeye çalışılmıştır.

\section{YÖNTEM}

$\mathrm{Bu}$ bölümde araştırmanın modeli, katılımcıları, veri toplama aracının geliştirilmesi, verilerin toplanması ve analizi, geçerlilik, güvenirlik, araştırmacıların rolüne yer verilmiştir.

\subsection{Araştırmanın Modeli}

$\mathrm{Bu}$ araştırma, nitel araştırma desenlerinden biri olan fenomenoloji desen kullanılarak yürütülmüştür. Burada araştırılacak olan fenomen; "okul gürültüsü" şeklinde ele alınmıştır. Fenomenoloji deseni; bir betimleme olmasının yanı sıra, kişilerin bir olguya dair tecrübelerini, algılarını, tutumlarını, bu olgunun bireye çağrıştırdıklarını ve araştırması yapılan olgunun yapısı ve özünü ortaya çıkarmayı hedeflemektedir (Creswell, 2016; Ersoy, 2016; Merriam, 2013; Yıldırım ve Şimşek, 2011).

\subsection{Katılımcilar}

Araştırma, Aydın ilinde araştırmaya gönüllü olarak katılan 10 farklı okulda görev yapan sınıf öğretmenleri ile yürütülmüştür. Okullar ve öğretmenler, araştırmacinın görüşme yapacağı kişilere ulaşması ve görüşmelerini öğretmenlere ve kendisine uygun olan zaman dilimlerinde yapabilmesi adına amaçlı örnekleme yöntemlerinden kolay ulaşılabilir ve ölçüt örnekleme kullanılmıştır. Buradaki ölçüt, öğretmenlerin sınıf öğretmeni olması ve 10 yılın üzerinde mesleki kıdemlerinin olmasıdır. Ayrıca araştırmada hem kalabalık hem orta düzeyde hem de mevcudu az olan okullar seçilerek maksimum çeşitlilik örnekleme yöntemi de kullanılmıştır. Katılımcılara ait bilgiler Tablo 2'de sunulmuştur. 
Tablo 2: Kat1lımcılara Ait Bilgiler

\begin{tabular}{|l|c|c|c|c|}
\hline $\begin{array}{c}\text { Kod } \\
\text { Adlar }\end{array}$ & Cinsiyet & Kıdem Yılı & $\begin{array}{c}\text { Okuldaki Öğrenci } \\
\text { Mevcudu }\end{array}$ & $\begin{array}{c}\text { Okuldaki } \\
\text { Öğretmen } \\
\text { Mevcudu }\end{array}$ \\
\hline Salih & $\mathrm{E}$ & 24 & 240 & 19 \\
\hline Hatice & $\mathrm{K}$ & 24 & 240 & 20 \\
\hline Selim & $\mathrm{E}$ & 28 & 235 & 20 \\
\hline Emre & $\mathrm{E}$ & 30 & 500 & 26 \\
\hline Yusuf & $\mathrm{E}$ & 20 & 450 & 24 \\
\hline Esma & $\mathrm{K}$ & 23 & 513 & 26 \\
\hline Elif & $\mathrm{K}$ & 18 & 1200 & 60 \\
\hline Zeynep & $\mathrm{K}$ & 12 & 210 & 60 \\
\hline Eren & $\mathrm{E}$ & 28 & 1125 & 50 \\
\hline Turan & $\mathrm{E}$ & 25 & 1000 & 6 \\
\hline
\end{tabular}

Tablo 2 incelendiğinde, araştırmanın 4'ü kadın, 6'sı erkek olmak üzere toplam 10 öğretmenle gerçekleştirildiği ve katılımc1 öğretmenlerin tamamının sınıf öğretmenlerinden oluştuğu görülmektedir. Öğretmenlerin kıdemlerinin ise; 12 ile 30 yıl arasında olduğu, çalışmakta oldukları okullardaki öğrenci sayısının ortalama olarak 200 ile 1200 arasında değiştiği ve okullarının öğretmen sayılarının 19 ile 60 arasında olduğu görülmektedir.

\subsection{Veri Toplama Aracının Geliștirilmesi}

Çalışmada veri toplama aracı olarak sınıf öğretmenlerine yönelik "Okul Gürültüsüne İlişkin Yarı Yapılandırılmış Görüşme Formu” kullanılmıştır. Görüşme formunun hazırlanması için alan yazın taraması yapılmış, konuyla ilgili diğer çalışmalar (Adıgüzel, 2011; Bulunuz ve Güner, 2017; Evans, Hygge ve Bullinger, 1995; Evans ve Maxwell 1997; Güremen, 2012; Polat ve Buluş-Kırıkkaya, 2004; Stansfeld vd. 2005; Şahin, Şahin ve Bağc1, 2014; Şan, 2010; Tuncer, Bal, Özüt ve Köse, 2012 vb. gibi) incelenmiştir. Elde edilen verilerden yola çıkarak, taslak bir form hazırlanmış ve uzman görüşü almak üzere üç farklı üniversiteden üç farklı öğretim üyesine e-mail yoluyla taslak form gönderilmiştir. Görüşme formu, "Eğitim Yönetimi" alanında uzman öğretim üyeleri tarafından incelenmiş, onların görüşleri doğrultusunda forma son şekli verilmiştir. Hazırlanan görüşme formu iki bölümden oluşmaktadır. Birinci bölümde demografik; ikinci bölümde ise okuldaki gürültünün seviyesi, kaynakları, en çok ne zaman ve nerelerde yoğunlaştığı, gürültü karşısında ne tür tepkiler verildiği, 
öğretmenleri nasıl etkilediği, okul yöneticilerinin bu konuda ne tür önlemler aldığ 1 ve gürültünün önlenmesine yönelik öğretmenlerin önerilerine ilişkin sorulara yer verilmiştir.

Görüşmeler öğretmenlerin izinleri doğrultusunda ses kaydına alınmıştır. Ses kaydına alınması ile verilerin eksik ya da yanlış olma ihtimali büyük oranda ortadan kaldırmıştır. Ses kaydı sırasında görüşme yapılan sınıf öğretmenlerinin ve okulun isminin belirtilmemesine özen gösterilmiştir. Öğretmenlerden elde edilen verileri kimliklerini açıklamadan sunabilmek ve karışıklığa sebebiyet vermemek için, katılımcılara kod adlar verilerek çalışma yürütülmüştür.

\subsection{Verilerin Toplanması ve Analizi}

Veri toplama süreci; öğretmenlerin uygun oldukları farklı zaman dilimlerinde ve yerlerde (ögretmenler odasında, görüşme yapılan kişinin evinde vb. gibi) önceden randevu alınmak suretiyle gerçekleştirilmiştir. Görüşmecilerden izin alınarak ses kayıt cihazı ile veriler kaydedilmiştir. Araştırmaya katılan öğretmenlere araştırma hakkında bilgi verilerek araştırmaya başlanmıştır. Öğretmenler araştırmaya gönüllülük esasına dayanarak, zorlama yapılmaksızın dâhil edilmişlerdir. Ayrıca katılımcıların kendilerini açık bir şekilde ifade edebilmeleri için; çalışmada gerçek isimlerinin kullanılmayacağı ve her katılımcıya farklı bir kod ad verileceği de sık sık tekrarlanmıştır.

Katılımcılarla yapılan görüşmeler ortalama olarak 20 dakika sürmüştür. Görüşme esnasında alınan ses kayıtları dinlenerek, bilgisayar üzerinden yazıya geçirilmiştir. Yazıya geçirilen veriler toplam 62 sayfa tutmuştur. Verilerin çözümlenmesi sırasında, yazılı metin haline getirilen görüşler içerik analizi yöntemi kullanılarak analiz edilmiştir. Birbirine yakın veriler, belli başlı temalar dâhilinde bir araya getirilip okuyucunun kolaylıkla anlayabileceği şekilde yorumlanmış ve yazıya geçirilmiştir (Yıldırım ve Şimşek, 2011).

\subsection{Geçerlik ve Güvenirlik Çalışmaları}

Araştırma kapsamında oluşturulan görüşme sorularının taslağı, geçerliğin sağlanması adına uzman görüşü için üç farklı üniversiteden "Eğitim Yönetimi" alanında uzman hocalara iletilmiştir. Alınan dönütlere göre sorular yeniden düzenlenmiştir. Toplanan veriler içerik analizi yapılarak araştırmacı ile danışman tarafından temalara ve alt temalara ayrılmıştır. Bu ayrım sırasında görüş birliği ve görüş ayrılığ yaşanan kodlar tespit edilmiş ve görüş birliğine varılan kodların sayısı tüm kodların sayısına bölünerek kodlayıcılar arası güvenirlik hesabı yapılmıştır. $\mathrm{Bu}$ işlem sonucunda elde edilen güvenirlik oranı \%98.7 olarak hesaplanmıştır. Yapılan 
bu işlem sonucunda oranın \%80'den büyük bir oran çıkması o araştırmayı güvenilir kılmaktadır (Miles ve Huberman, 1994). Buna göre araştırma güvenilir kabul edilmiştir.

\subsection{Araştırmacıların Rolü}

Araştırmada kullanılan yöntem, veri toplama aracı, toplanan veriler açık ve detaylı, önyargısız bir şekilde anlatılmıştır. Kullanılan kaynakların eksiksiz ve kusursuz şekilde belirtilmesi hususunda titiz davranılmış; kaynaklar atıflarla belirtilmiş, gizliliği olan kaynaklar kullanılmamıştır. Çalışmanın başından sonuna kadar objektiflik ilkesine dikkat edilmiş, katılımcıların kişisel bilgileri gizli tutulmuştur. Katılımcılardan alınan veriler kod adlar kullanılarak ilgili bölümlerde doğrudan çalışmaya dâhil edilmiştir. Doğrudan alıntılar verilirken, hiçbir değişiklik yapılmadan yazıya aktarılmıştır. Araştırma süresince, konu dağıtılmadan ve saptırılmadan, bilimsel etik kurallarına dikkat edilerek çalışma noktalanmıştır.

\section{BULGULAR}

$\mathrm{Bu}$ bölümde, katılımcıların görüşleri doğrultusunda elde edilen bulgular incelenmiştir.

\subsection{Okul Ortamındaki Gürültü}

Bu bölüm; sınıf öğretmenlerinin okul ortamındaki gürültü kavramına ilişkin görüşlerini içermektedir. Yapılan içerik analizi sonucu elde edilen bulgular Tablo 3'te verilmektedir.

Tablo 3: Okul Ortamındaki Gürültü (Okul Gürültüsü)

\begin{tabular}{|l|l|r|}
\hline \multicolumn{1}{|c|}{ Temalar } & \multicolumn{1}{|c|}{ Alt Temalar } & f \\
\hline \multirow{3}{*}{$\begin{array}{l}\text { İnsana Ait } \\
\text { Sesler }\end{array}$} & $\begin{array}{l}\text { Bir veya birçok kişinin aynı anda, yüksek sesle ya da sürekli } \\
\text { konuşması }\end{array}$ & 5 \\
\cline { 2 - 3 } & Öğrencilerin sebepsiz yere bağırarak konuşmaları & 3 \\
\cline { 2 - 3 } & Öğrenci sayısıyla orantılı olarak ses seviyesinin yüksekliği & 2 \\
\hline $\begin{array}{l}\text { İnsan Dışı } \\
\text { Sesler }\end{array}$ & Çocuk sesi dışındaki sesler (Materyallerden kaynaklanan sesler) & 3 \\
\hline \multirow{2}{*}{$\begin{array}{l}\text { İnsan ve } \\
\text { İnsan Dışı } \\
\text { Sesler }\end{array}$} & $\begin{array}{l}\text { Okulun bulunduğu konumun karayoluna yakınlığı ve başka bir } \\
\text { okulla aynı bahçeyi paylaşması }\end{array}$ & 3 \\
\cline { 2 - 3 } & İnsanları rahatsız eden tüm sesler topluluğu & 2 \\
\cline { 2 - 3 } & Ders esnasında oluşan ve dikkati dağıtan her türlü ses \\
\hline \multicolumn{2}{|c|}{ Toplam } & 20 \\
\hline
\end{tabular}

Tablo 3 incelendiğinde, katılımcı öğretmenlerin okul gürültüsü kavramına ilişkin olarak 3 tema ve 7 alt temada birleştikleri, bu alt temalara yönelik olarak 20 söylemlerinin olduğu tespit edilmiştir. Katılımcıların çoğunun okul gürültüsünü bir veya birçok kişinin aynı anda, yüksek sesle ya da sürekli konuşması olarak tanımladıkları göze çarpmaktadır. Bunun 
dışında katılımcılar okul gürültüsünü insanları rahatsız eden sesler, çocuk sesi dışındaki sesler, öğrencilerin sebepsiz yere bağırarak konuşmaları, okulun bulunduğu konumun karayoluna yakınlığı ve başka bir okulla aynı bahçeyi paylaşması, öğrenci sayısıyla orantılı olarak ses seviyesinin yüksekliği, ders esnasında oluşan ve dikkati dağıtan her türlü ses şekillerinde tanımlamışlardır. Katılımcıların okul ortamındaki gürültü kavramına dair görüşlerine örnekler aşağıda verilmiştir.

"Çocuk sesini çok gürültü olarak almıyorum ama sıra sesleri çekiştirme sesleri oradan oraya sıra çekme genelde bu sesler daha fazla rahatsız etme, kapı çarpma, hani benim gürültü olarak algıladı̆̆ım okulda herhalde çocuk sesi dlşındaki sesler.” (Hatice).

"Gürültü denince; birçok ögrencinin veya birçok insanın aynı anda konuşması ve yüksek sesle konuşması ve tabii ki ortam gürültülü olduğu için ister istemez çocuklar biraz daha yüksek sesle konuşma ihtiyacı hissettikleri için ses yükseliyor ve bu da genele baktı̆̆ımızda gürültü̈ oluş̧urmuş oluyor." (Selim).

"Sebepsiz çı̆̆lıklar, ders esnasında pet şişelerin sürekli sikılmasından ortaya çıkan sesler, çocukların işte tık, tık, tık kalem vurmaları rahatsız edici sesler anlamlina geliyor aslinda." (Esma).

\subsection{Okullardaki Gürültünün Seviyesi}

Sınıf öğretmenlerinin çalışmakta oldukları okullardaki gürültünün seviyesine ilişkin görüşleri için yapılan içerik analizi sonucu elde edilen bulgular Tablo 4'te verilmektedir.

Tablo 4: Okullardaki Gürültünün Seviyesi

\begin{tabular}{|c|l|r|}
\hline Tema & \multicolumn{1}{|c|}{ Alt Temalar } & f \\
\hline \multirow{3}{*}{$:$} & Yüksek düzeyde & 7 \\
\cline { 2 - 3 } & Orta düzeyde & 2 \\
\cline { 2 - 3 } & Düşük düzeyde & 1 \\
\cline { 2 - 3 } & Toplam & 10 \\
\hline
\end{tabular}

Tablo 4 incelendiğinde; görüşme yapılan öğretmenlerin çalıştıkları okulların gürültü seviyesine dair yüksek, orta ve düşük olmak üzere 3 alt tema oluşturdukları görülmektedir. Katılımcı öğretmenlerin çalıştıkları okulları büyük oranda yüksek düzeyde gürültülü olarak niteledikleri görülmektedir. Bunun yanında okullarını orta ve düşük seviyede gürültülü bulan öğretmenler de vardır. Katılımcıların çalıştıkları okullardaki gürültünün seviyesine ilişkin görüşleri aşağıda belirtilmiştir:

“Çocuklar belki yaş seviyeleri düşü̈g̈̈ için ilk 4'te olduğumuz için en yetişkin çocuğumuz 10-11 yaşında 4. Sinıf ögrencisi. Onun da ses yükseltip 
gürültü oluşturabilecek bir şeyi yok o yüzden rahatız, okulda aşırı derecede rahatsız edici gürültü olmuyor." (Selim)

"Çok yüksek. Özellikle teneffüslerde tahammül edilemeyecek oranla yüksek sese maruz kalyyoruz." (Esma)

"Çok aşırı gürülttülü bir okul değil, disiplin anlamında sıkıntı yaşanan bir okul değil. Rahat bir okul çok az bir gürültü var diyemem, çok yüksek bir dozda da gürültü var diyemem orta diyebilirim. Sanırım siniflara göre de gürültü değişiyor. Her sinıfta aynı gürültü yok çünkü. “ (Zeynep)

\subsection{Okullardaki Gürültünün Kaynakları}

Sınıf öğretmenlerinin çalışmakta oldukları okullardaki gürültünün kaynaklarına ilişkin görüşlerini içeren bulgular Tablo 5'te verilmektedir.

Tablo 5: Okullardaki Gürültünün Kaynakları

\begin{tabular}{|c|c|c|}
\hline Temalar & Alt Temalar & $\mathbf{f}$ \\
\hline \multirow{4}{*}{$\begin{array}{l}\text { İnsandan } \\
\text { Kaynaklanan }\end{array}$} & Öğrencilerin gereksiz bağrışmaları ve çığlıkları & 8 \\
\hline & $\begin{array}{l}\text { Oyun ve fiziki etkinlikler ile sosyal etkinlikler derslerinin } \\
\text { kaliteli ișlenmemesi }\end{array}$ & 2 \\
\hline & Okulların çok kalabalık olması & 2 \\
\hline & Ders esnasında görüşmeye gelen veliler & 1 \\
\hline \multirow{4}{*}{$\begin{array}{c}\text { İnsan Dışı } \\
\text { Herseyden } \\
\text { Kaynaklanan }\end{array}$} & Okulun fiziki koşulları & 5 \\
\hline & $\begin{array}{l}\text { Kullanılan materyallerin gürülttüye yatkınlığı ve yanlış ve } \\
\text { özensiz kullanımı }\end{array}$ & 4 \\
\hline & Okulların konumu & 3 \\
\hline & Toplam & $\begin{array}{l}2 \\
5\end{array}$ \\
\hline
\end{tabular}

Tablo 5 incelendiğinde; okulda yaşanan gürültünün en büyük kaynağının öğrencilerin gereksiz bağrışmaları ve çı̆̆lıklarının olduğu görülmektedir. Bunun yanında katılımcı öğretmenler kullanılan materyallerin gürültüye yatkınlığını, yanlış ve özensiz kullanımını, okulların konumunu, ders esnasında görüşmeye gelen velileri, oyun ve fiziki etkinlikler ile sosyal etkinlikler derslerinin kaliteli işlenmemesini, okulun fiziki koşullarını ve okulların çok kalabalık olmasını da gürültüye kaynaklık yapan etmenler olarak ortaya koymuşlardır. Katılımcıların çalıştıkları okullardaki gürültünün kaynaklarına ilişkin görüşleri aşağıda belirtilmiştir:

“Okuldaki gürültünün kaynakları yalttılmamış pencereler, ayaklarına plastik takılmamış sandalyeler, sıralar. Benim için gürültünün kaynakları bunlar. Çocuk sesini gürültü olarak kabul etmiyorum...." (Hatice)

“Okuldaki gürültünün kaynakları dersek tek çocuk değildir, bu çevresel etkenlerde olabilir. Yakında büyük bir kara yolunun olması, dış 
140/ Aslıhan Kenber Çiftçi, Bilgen Kıral, "Sınıf Öğretmenlerinin Okul Gürültüsüne İlişkin Görüşleri” (128-149)

etkenlerde vardır. Çocukların yüksek sesle konuşmaları da vardır. Ben şunu da belirteyim çocukların yüksek sesle konuşmalarının nedenleri aileden de kaynaklanan bazı sebepler var, bu da belirlendiği takdirde bunun da önüne geçilebilir. "(Yusuf)

"Bence mesela düşününce velilerin ders esnasinda gelip görüşme yapmaları bu sebeplerden biridir. Konuşmak istemeleri, koridorda konuşuyorsun diğer sınıf rahatsız oluyor. Beden eğitimi derslerinde ögretmenlerin başlarında durmayıp ögrencileri serbest buraktıkları takdirde sınıfa giriş çıkışlar, WC'leri kullanmalar, diğer ders yapan öğretmenleri acayip rahatsiz ediyor ve bu beni de rahatsız ediyor." (Elif)

\subsection{Okul Gürültüsünün Yoğunlaştığı Yerler ve Zamanlar}

Sınıf öğretmenlerinin çalıştıkları okullardaki gürültünün yoğunlaştığı yerlere iliş̧kin bulgular Tablo 6'da verilmiştir.

Tablo 6: Okullardaki Gürültünün Yoğunlaştığı Yerler

\begin{tabular}{|c|c|c|}
\hline Tema & Alt Temalar & $\mathbf{f}$ \\
\hline \multirow{5}{*}{$\begin{array}{l}\text { Okulda } \\
\text { Gürülttünün } \\
\text { Yoğunlaştığı } \\
\text { Yerler }\end{array}$} & Koridorlarda & 4 \\
\hline & Okul binasının içinde & 4 \\
\hline & Bahçede & 3 \\
\hline & Kantinde & 1 \\
\hline & Toplam & 12 \\
\hline
\end{tabular}

Tablo 6'ya göre ise katılımcı öğretmenler okul gürültüsünün yaşandığı yerleri ise koridorlarda, bahçede, okul binasının içinde ve kantinde şeklinde belirtmişlerdir. Ancak Tablo 6 incelendiğinde okul gürültüsünün en yoğun yaşandığı yerlerin koridorlar ve okul binasının içi olduğu göze çarpmaktadır. Sınıf öğretmenlerinin çalıştıkları okullardaki gürültünün yoğunlaştığı zamana ilişkin bulgular Tablo 7'de verilmiştir.

Tablo 7: Okullardaki Gürültünün Yoğunlaştığı Zamanlar

\begin{tabular}{|c|c|c|}
\hline Tema & Alt Temalar & f \\
\hline \multirow{7}{*}{$\begin{array}{l}\text { Gürülttünüin } \\
\text { Yoğunlaştığı } \\
\text { Zamanlar }\end{array}$} & Tenefüslerde & 5 \\
\hline & Öğle arasında & 3 \\
\hline & Beslenme teneffüsünden sonraki saatlerde & 2 \\
\hline & Dersten çıkış ve derse giriş sırasında & 2 \\
\hline & Öğleden sonraki saatlerde & 1 \\
\hline & Öğretmenler toplantıda iken & 1 \\
\hline & Öğrenci zili ile öğretmen zili arasındaki sürede & 1 \\
\hline & Toplam & 15 \\
\hline
\end{tabular}

Tablo 7'ye göre katılımc1 öğretmenler okul gürültüsünün yaşandığı zamanları; öğleden sonraki saatler, beslenme teneffüsünden sonraki saatler, 
dersten çıkış ve derse giriş sırası, teneffüsler, öğle arası, öğretmenler toplantıda iken ve öğrenci zili ile öğretmen zili arasındaki sürede şeklinde belirtmişlerdir. Ancak Tablo 7 incelendiğinde okul gürültüsünün en yoğun yaşandığı zaman teneffüsler olarak dikkat çekmektedir. Katılımcıların çalıştıkları okullardaki gürültünün yoğunlaştığı zaman ve okul bölümlerine ilişkin görüşleri aşağıda belirtilmiştir:

"Gürültü genelde öğleden sonraki saatlerde biraz daha yoğun olarak görüyorum ben. Bir de beslenme 10.30'dan öğle saatine kadar olan sürede çocuklar daha aktif oluyorlar. Sabahlar biraz daha uysal oluyorlar gürültü o saatlerde biraz daha az oluyor ama bilhassa öğleden sonra gürültü biraz daha fazla oluyor. Bu da dışarıda oynama beklentisi olduğu için hep de o saatler topladığımız için oyun saatini o yüzden o beklentinin de etkisi ile gürültü biraz daha fazla oluyor. " (Salih)

"Ders sırasında gürültü olayı olmuyor ama teneffüsün başlaması ile birlikte çocukların koridorlara çıkması ile birlikte sanki bir savaş alanına çıkıyormuş gibi ya da kovandan çıkmış arılar gibi düşününün. Aynı o şekilde gürültü oluyor, genellikle teneffüs saatlerinde koridorlarda oluyor. Belki de dışarıda da aynı gürültüyü yapıyorlar ama ses dă̆ıldiğg için bu kadar yüksek düzeyde olmuyor ve rahatsız edici olmuyor." (Yusuf)

\subsection{Okul Gürültüsünün Öğretmenler Üzerindeki Etkileri}

Okul gürültüsünün öğretmenlerin özel hayatlarında ne şekilde etkilediğine yönelik öğretmen görüşleri Tablo 8'de verilmiştir.

Tablo 8:Okul Gürültüsünün Öğretmenlere Etkileri

\begin{tabular}{|c|l|r|}
\hline \multirow{2}{*}{ Temalar } & \multicolumn{1}{|c|}{ Alt Temalar } & f \\
\hline \multirow{2}{*}{ Bedensel } & Yoğun bir yorgunluk hissi bırakması & 7 \\
\cline { 2 - 3 } & Sağlığı olumsuz etkilemesi & 4 \\
\hline \multirow{2}{*}{ Psikolojik } & Sese tahammülün azalması & 6 \\
\cline { 2 - 3 } & Yaşam kalitesinin azalması & 1 \\
\hline \multirow{2}{*}{ Eğitsel } & Eğitsel performansın düşmesi & 3 \\
\hline Ailesel & Aileye nitelikli zaman ayırmakta zorlanılması & 6 \\
\hline Etkilememe & Özel hayatı etkilememesi & 1 \\
\hline Toplam & 28 \\
\hline
\end{tabular}

Tablo 8 incelendiğinde; gürültünün görüşmecilerin özel hayatlarına etkisine yönelik 28 görüş olduğu göze çarpmaktadır. Bu söylemler; eğitsel performansı düşürme, sağlığı olumsuz etkileme, yoğun bir yorgunluk hissi bırakma, özel hayatı etkilememe, sese tahammülün azalması, yaşam kalitesini azaltması, aileye nitelikli zaman ayırmakta zorlanma şeklinde alt temalar halinde belirlenmiştir. Belirlenen bu alt temaların içinde 
katılımcıların yoğunlukla vurgu yaptığı etki ise gürültünün yorgunluk hissi bıraktığı yönündeki alt temadır. Katılımcıların okullardaki gürültüden özel hayatlarındaki etkilerine ilişkin görüşleri aşağıda belirtilmiştir:

"Bana en büyük etkisi evde çocuklarıma karşı sabırsız olmam ve artık sürekli ses olduğu için anne demeleri bile bazen beni rahatsiz ediyor. TV izlemiyorum bir süre, müzik dinlemiyorum. Okuldan geldiğim belli bir saat diliminde biraz dinlenmek istiyorum." (Elif)

"Mutlaka her insanı gürültü etkiler hani bazen kendinizi çok yorgun, gürültü en çok insanı psikolojik olarak zihin olarak yorar. Kendinizi sürekli yorgun hissetmenize neden olabilir." (Eren)

"Kesinlikle etkiliyor. Az önce dediğim gibi sağlık sorunları başlamaya başladl. Eve gittiğim zaman kendimi çok yorgun hissediyorum. Kendimi attyorum bir yerlere kanepeye attyorum, uzantyorum. Gürültüye tahammül edemiyorum çoğu zaman..." (Turan)

\subsection{Okul Yönetiminin Gürültüyü Azaltmak ya da Yok Etmek} Amacıyla Yaptığı Çalışmalar

Okul yöneticilerinin var olan gürültünün azaltılmasını veya yok edilmesini sağlamak amacıyla yaptığı çalışmalara yönelik sınıf öğretmenlerinin görüşleri Tablo 9'da verilmiştir.

Tablo 9: Okul Yönetiminin Gürültü İçin Yaptığı Çalışmalar

\begin{tabular}{|l|l|c|}
\hline \multicolumn{1}{|c|}{ Tema } & \multicolumn{1}{|c|}{ Alt Temalar } & f \\
\hline \multirow{3}{*}{$\begin{array}{l}\text { Okul } \\
\text { Yönetiminin } \\
\text { Gürülttü } \\
\text { İçin }\end{array}$} & Herhangi bir çalışma yapılmaması & 3 \\
\cline { 2 - 3 } $\begin{array}{l}\text { Yaptı̆ğ } \\
\text { Çalışmalar }\end{array}$ & Toplantıların yapılması & 2 \\
\cline { 2 - 3 } & Müdürün öğrencileri ikaz etmesi & 2 \\
\cline { 2 - 3 } & Nöbetçi öğretmenlerin uyarılması & 2 \\
\cline { 2 - 3 } & Aynı bahçeyi paylaşan okulların teneffüs saatlerinin düzenlemesi & 2 \\
\cline { 2 - 3 } & Müdürün öğretmenleri uyarması & 2 \\
\cline { 2 - 3 } & $\begin{array}{l}\text { Öğretmenlerin derse giriş ve dersten çıkış saatlerinin idarece } \\
\text { takip edilmesi }\end{array}$ & 1 \\
\hline & Toplam & 14 \\
\hline
\end{tabular}

Tablo 9 incelendiğinde; okul idarecilerinin gürültüye yönelik olarak yaptıkları çalışmalar 14 söylemde dile getirilmiştir. Bunlar "toplantılar yapılması, herhangi bir çalışma yapılmaması, müdürün öğrencileri ikaz etmesi, nöbetçi ögretmenlerin gürültü hassasiyeti konusunda uyarllmast, müdürün öğretmenleri sınıfta gürültü kirliliği konusunu işlemesi konusunda uyarması, aynı bahçeyi paylaşan okulların teneffüs saatlerini düzenlemesi ve ögretmenlerin derse giriş ve dersten çıkış saatlerinin idarece takip edilmesi" şeklinde belirlenmiştir. Katılımcı öğretmenlerin büyük çoğunluğu okul idarelerin gürültü konusunda herhangi bir çalışma yapmadıklarını beyan 
etmiştir. Katılımcıların çalıştıkları okulların yöneticilerinin var olan gürültüyü azaltmak ya da yok etmek adına yaptıkları çalışmalara ilişkin görüşleri aşağıda belirtilmiştir:

"Okul yöneticimiz daha çok ögretmenlerin sinıflarda bu konuyu işlemeleri yönünde telkinde bulunuyor, kendisi ekstra bir çaba sarf etmiyor, diyor ki biz bu işi ögrencilerimi derste bu konu hakkında bilgilendirerek yapabiliriz. Çünkü ögrenciler ile muhatap olan öğretmenler o yüzden bizlere atıyor topu daha çok biz işte dediğim gibi dersler, teneffüslerde çocuklara uyararak azaltmaya çalışlyoruz ama çokta azaldiğını söyleyemem yani, çocuk neticede o sesi çıkaracak o enerjiyi atacak. Bizim için rahatsı edici, onlar için enerjiyi boşaltma yolu." (Esma)

\subsection{Gürültünün Azaltılmasına veya Yok Edilmesine Yönelik Sınıf Öğretmenlerinin Önerileri}

Okullarda var olan gürültünün azaltılmasına veya yok edilmesine yönelik sınıf öğretmenlerinin öneri ve görüşleri Tablo 10'da verilmektedir.

Tablo 10: Gürültü İçin Öğretmenlerin Önerileri

\begin{tabular}{|c|c|c|}
\hline Temalar & Alt Temalar & f \\
\hline \multirow{4}{*}{$\begin{array}{c}\text { Öğrenci } \\
\text { dışındaki } \\
\text { unsurlara } \\
\text { yönelik } \\
\text { çalışmalar }\end{array}$} & $\begin{array}{l}\text { Sınıfların, okulların ve okul bahçelerinin fiziki koşullarının } \\
\text { ivilestirilmesi }\end{array}$ & 5 \\
\hline & İlk 4 saat akademik, son iki saat beceri ve sosyal etkinliklerin olması & 2 \\
\hline & Teneffüs sürelerinin uzatılmas1 & 2 \\
\hline & $\begin{array}{l}\text { Teneffüslerde okulda ve bahçede müzik yayını yapılmas1 ve zillerin } \\
\text { dinlendirici müziklerden seçilmesi }\end{array}$ & 1 \\
\hline \multirow{13}{*}{$\begin{array}{c}\text { Öğrencilere } \\
\text { yönelik } \\
\text { çalışmalar }\end{array}$} & Öğrencilerin ikaz edilmesi & 3 \\
\hline & Beden eğitimi ve serbest etkinlikler dersi daha verimli işlenmesi & 2 \\
\hline & $\begin{array}{l}\text { Öğrenciler enerjilerini boşaltabilmek için sokak ve bahçe oyunlarına } \\
\text { yönlendirilmesi }\end{array}$ & 2 \\
\hline & Öğretmenler model olması & 2 \\
\hline & $\begin{array}{l}\text { Ögretmenlerin de öğrenci oyunlarına katılım olumsuzluklara anında } \\
\text { müdahale etmesi }\end{array}$ & 1 \\
\hline & Gürültünün zararlarının derslerde işlenmesi & 1 \\
\hline & Öğrencilere sesini ortama ve amaca göre ayarlamasının öğretilmesi & 1 \\
\hline & Öğrencilerin fazla enerji veren gıdalardan uzak tutulması & 1 \\
\hline & Öğle aralarında okulda öğrenci kalmaması, evine gitmesi & 1 \\
\hline & Öğrenciye boş zaman bırakılmaması & 1 \\
\hline & $\begin{array}{l}\text { Öğrencilere öğretmen sınıfa gelene kadar oynayabilecekleri küçük } \\
\text { gruplu sınıf içi oyunlar öğretilmesi }\end{array}$ & 1 \\
\hline & $\begin{array}{l}\text { Gürültü kirliliğini anlatan etkinliklerin düzenlenmesi, filmlerin } \\
\text { izletilmesi }\end{array}$ & 1 \\
\hline & Toplam & 27 \\
\hline
\end{tabular}

Tablo 10 incelendiğinde; var olan gürültünün azaltılmas1 veya yok edilmesi adına görüşmeci öğretmenlerin 27 söylemi olmuştur. Katılımcıların 
çalıştıkları okullardaki gürültünün azaltılmasına veya yok edilmesine yönelik önerilerinin yer aldığı görüşleri aşağıda belirtilmiştir:

"Önce çocuğu karşımızda bir birey olarak düşünüp onunla konuşurken sakin konuşup örnek olup ona ve sinıf olarak da yüksek sesle konuşmaması gerektiğinin anlatmak istediklerini daha sakin anlattı̆̆ında daha iyi amacına ulaşacă̆ını söylediğimizde gürültü olayının daha azalacağını düşünüyorum. " (Yusuf)

"Beden eğitimi derslerinde sorun olarak dile getirdiğim çocukların serbest bırakılması durumu, diğer öğrenciler için gürültü kirliliği olduğu anlamında ögrretmenler ögrencilerin başında olup etkinlik yaptırabilirler" (Elif)

\section{SONUÇ, TARTIŞMA ve ÖNERILER}

Yapılan çalışmada gürültü, gürültünün seviyesi, kaynakları, yoğunlaştığ1 yer ve zamanlar, gürültünün etkileri, okul yönetiminin gürültü ile ilgili çalışmaları ve gürültünün azaltılması için yapılması gerekenler öğretmen görüşleri doğrultusunda incelenmiştir. Öncelikle öğretmenler gürültü kavramını birden çok kişinin konuşması, bağırması yüksek sesler, materyal sesleri olarak tanımlamışlardır. Bu tanımlar alan yazında geçen gürültünün tanımı ile benzerlik göstermektedirler (Polat ve Buluş-Kırıkkaya, 2004).

Yapılan çalışmada gürültü seviyesi ile ilgili elde edilen bulgular daha önce yapılan çalışmalarla da benzerlik göstermektedir. Bulunuz ve diğerlerinin (2015) araştırmasında da öğretmenler okullarındaki gürültü seviyesinin yüksek olduğunu belirtmişlerdir. Ayrıca öğretmenler, gürültü kaynaklarına ilişkin; öğrencilerin gereksiz bağırmaları, okulun fiziki koşulları ve okulda kullanılan araç-gereçlerin sesleri olduğunu ifade etmişlerdir. Okullardaki gürültü kaynakları ile ilgili öğretmen görüşlerinin Bulunuz ve diğerlerinin (2015) yaptığ 1 çalışmada elde ettikleri sonuçlarla benzerlik gösterdiği belirlenmiştir.

Öğretmenlerin okullardaki gürültünün yoğunlaştığı zamanlar ve yerler konusundaki görüşleri; gürültünün teneffüs, öğle arası ve ders giriş çıkışlarında, ayrıca okul koridorları ve bina içinde gürültünün yoğunlaştı̆̆ yönündedir. Gürültünün öğretmenlere olumsuz etkisi ile ilgili görüşler, gürültünün öğretmenlerde yorgunluk hissi oluşturduğu, tahammül sınırlarını azalttığ 1 , aile ile kaliteli vakit geçirme süresini azalttığ1 ve sağlı problemlerine yol açtığı şeklindedir. Öğretmenlerde meydana gelen olumsuz değişimler eğitim kalitesini de azaltacaktır. Gürültülü bir ortamda işlenen dersin öğretmenlerin öğretme ve eğitme performanslarını olumsuz 
etkileyeceği düşünülmektedir. Bu noktada öğrencilerin akademik başarısını yükseltmek için okullardaki gürültünün engellenmesi iyi bir çözüm olabilir. Okulda günlerinin büyük bir bölümünü geçiren öğretmen ve öğrencilerin hem psikolojik hem de fizyolojik olarak daha sağlıklı olmaları için de okullarda var olan gürültünün seviyesinin düşürülmesi ve önlenmesinin çok önemli olduğu söylenebilir. Alan yazının da bu sonucu destekler nitelikte olduğu görülmektedir (Güremen, 2012; Hayta, 2007; Şahin, Şahin ve Bağc1, 2014).

Öğretmenlerin okul yönetiminin çalışmaları ile ilgili görüşleri büyük oranda gürülttü ile ilgili çalışma yapılmadığı yönündedir. Yapılması gereken çalışmalar ile ilgili öğretmenler; özellikle idarecilerin bu konuda uyarılarda bulunmaları ve bu problemi ciddiye almaları gerektiğini belirtmişlerdir. Ayrıca ortak bahçe kullanan okulların teneffüs saatlerinin ayarlanması gerektiğini ve nöbetçi öğretmenlerin teneffüs saatlerinde meydana gelen gürültü̈ye karşı hassas olması gerektiğini belirtmişlerdir.

Son olarak öğretmenlerin gürültünün engellenmesi ya da azaltılmasına yönelik görüşleri şu şekildedir: Okul binalarının fiziki koşullarının iyileştirilmesi, öğrencilerin ikaz edilmesi ve enerjilerini boşaltacak aktivitelerin düzenlenmesi şeklinde sıralanabilir. Ayrıca ders saatlerinde değişiklik yapılarak sabah saatlerinde akademik çalışma, son saatlerde bedensel aktivite ya da sosyal etkinlikler düzenlenmelidir. Öğretmenler bu düşünceleri ile gürültünün okullarda azaltabileceğine inanmaktadırlar. Gürültü, öğretmen ve öğrenci arasındaki iletişimi bozarak eğitim-öğretimin verimin düşmesine yol açmaktadır. Gürültü sebebiyle öğrenci başarısı olumsuz olarak etkilenmektedir. Bunun yanı sıra; öğrenci ve öğretmenlerin ruhsal ve fiziksel olarak daha çabuk tükenmesine sebep olan gürültü, derse ilgiyi azaltan ve okul iklimini bozan önemli bir faktördür. Gürültü aynı zamanda duyu organlarına zarar verebilmekte, öğrenmenin daha etkili ve verimli gerçekleşebilmesi için gerekli olan beden ve ruh sağlığ uyumunu bozabilmektedir. Ortaya çıkan bu sağlık sorunları ise öğrenme performansında verimin düşmesine sebep olmaktadır (Bulunuz vd., 2018). Yapılan araştırmalar (Güremen, 2012; Şan, 2010; Şahin, Şahin ve Bağc1, 2014; Bulunuz ve Güner, 2017) gürültü ile öğrencilerin okuma, okuduğunu anlama, dikkat süresi, bilişsel işlem yapabilme becerisi ve bilgilerin uzun süreli belleğe aktarımının olumsuz yönde etkilendiğini tespit etmiştir.

Öğretmenlerin performansının artması ve daha kaliteli eğitim için okulda gürültü sorununun giderilmesine yönelik ulusal çapta araştırmalar yürütülebilir. Öğretmen yetiştiren kurumlarda gürültü kavramı üzerinde durularak ve öğretmen adaylarında gürülttï ile mücadele bilinci yerleştirilebilir. Öğrenciler için de gürültü konusunda dersler verilip; gürültü 
ile mücadele bilinci oluşturulabilir. Okul binalarında akustik iyileştirmeler yapılıp; gürültü oluşturan materyaller ses yalıtımı yapılmış sınıflar dizayn edilebilir. Okullardaki rehberlik servisleri gürültü konusunda öğrencilerle etkileşimde olabilir. Veliler de dâhil olmak üzere tüm okul bireyleri gürültü konusunda bilgilendirilip; gürültünün azaltılması konusunun önemi anlatılabilir. Aynı çalışma özel okullarda çalışan öğretmenlerle de yapılabilir. Ortaokul, lise, özel eğitim okulları gibi farklı eğitim kademelerinde benzer araştırmalar yapılabilir. Geliştirilecek olan ölçekle öğretmenler üzerinde gürültünün etkileri araştırılarak sonuçlar genellenebilir.

\section{KAYNAKÇA}

Adıgüzel, Abdullah (2011), Okul Değişkenlerinin Eğitimde Verimliliğe Etkisi, Düzce Üniversitesi Sosyal Bilimler Enstitüsü Dergisi,1(2),4564.

Akbaba, Ahmet ve Turhan, Mehmet (2016), İlköğretim Okul Binalarının Fiziksel Sorunlarına İlişkin Öğretmen Görüşlerinin İncelenmesi (Van İli Örneği), KTÜ Sosyal Bilimler Enstitüsü Sosyal Bilimler Dergisi, 341-357.

Alpteker, Hacer (2018), Okullarda Güvenlik Kültürünün Gelişmesinde Sağlık Eğitiminin Önemi, Uluslararası Güvenli Okullar, Çalışan Sağllğ ve İ̧̧ Güvenliği Semozyumu.

Avşar, Yaşar ve Gönüllü, M. Talha (2000), İstanbul İli Örneğinde Bazı Okullarda İç ve Dış Ortam Gürültülerinin Eğitim Kalitesi Açısından Değerlendirilmesi, GAP Çevre Kongresi, Şanlıurfa.

Bulunuz, Mizrap, Bulunuz, Nermin, Tavşanlı, Ömer F., Orbak, Ali Y. ve Mutlu, Nejla (2018), İlkokullarda Gürültü Kirliliğinin Düzeyi, Etkileri ve Kontrol Edilmesine Yönelik Sınıf Öğretmenlerinin Görüşlerinin Değerlendirilmesi, Kastamonu Eğitim Dergisi, 26(3), 661-671.

Bulunuz, Mızrap, Bulunuz, Nermin, Tavşanlı, Ömer F.ve Orbak, Ali (2015), Okulda Gürültü Kirliliğine Yönelik Geçerli ve Güvenir Veri Toplama Araçları Geliştirme Çalışması: Öğrenci ve Öğretmen Görüşlerinin Değerlendirilmesi, Bildiri Özetleri Kitabı, Ankara: Anı Yay.

Bulunuz, Mızrap ve Güner, Fatih (2017), Öğretmen Görüşlerine Göre Okulda Gürültü Düzeyinin Değerlendirilmesi: Fransa ve Türkiye Örneği, Turkish Studies, 12(35), 69-87. 
Creswell, John W. (2016), Nitel Araştırma Yöntemleri Beş Yaklaşıma Göre Nitel Araştırma ve Araştırma Deseni, M. Bütün ve S. B. Demir (Edt.), Ankara: Siyasal Kitabevi.

Ersoy, A. Figen (2016), Fenomenoloji, Saban, A. ve Ersoy, A. (Edt.), Ĕgitimde Nitel Araştırma Desenleri, Ankara: Anı yayıncılık.

Evans , Gary W. ve Maxwell, Lorrainne (1997), Chronic Noise Exposure and Reading Deficits: The Mediating Effects of Language Acquisition, Environment and Behaviour, 29(5), 638-656

Evans, Gary W.,Hygge Staffan ve Bullinger Monika (1995), Chronic Noise and Psychological Stress, Psychological Science, 6(6), 333-338.

Güney, Emrullah (1998), Çevre Sorunları, Ankara: Hatipoğlu.

Güremen, Lale (2012), Amasya Kentinde İlköğretim Okullarında İç ve Dış Çevre Gürültü Koşullarının Değerlendirilmesi, Engieering Sciences, $7(2), 415-435$.

Hayta, Ateş B. (2007), Çalışma Ortamı Koşullarının İşletme Verimliliği Üzerine Etkisi, Ticaret ve Turizm Eğitim Fakültesi Dergisi, 1, 21-41.

Imhof, Margarate, Henning, Nadine ve Kreft, Susanne (2009), Effects of Background Noise on Cognitive Performance in Elementary School Children, Listening Education. www.researchgate.net/publication/307856096_Effects_of_Backgroun d_noise_on_cognitive_performance_in_elementary_school_children.

Işık, Halil (2004), Öğrenme Ortamlarının Fiziksel Sınıf Yönetimi, Ankara: Pegem Yayıncilık.

Işıık, Halil (2015), Öğrenme Ortamlarının Fiziksel Düzeni. Şişman, M., Turan, S., (Editörler), Sınıf Yönetimi içinde (61-76), Ankara: Pegem Yayınc1lik.

Kıral, Bilgen (2016), Stres ve Okul Yönetimi, Ankara: EYUDER yayınları.

Maraş, Erdem E., Maraş, Hadi H., Maraş, S. Sırrı, ve Alkış, Zübeyde (2011), CBS Verilerinden Çevresel Gürültü Haritalarının Hazırlanmasında Kullanılan Tahmin Yönteminin Analizi, Harita Dergisi, 145, 52-60.

Maxwell, Lorrainne ve Evans , Gary W (2000), The Effects of Noise PreSchool Children's Pre-reading Skills, Journal of Environmental Psychology, 20, 91-97. 
148/ Aslıhan Kenber Çiftçi, Bilgen Kıral, "Sınıf Öğretmenlerinin Okul Gürültüsüne İlişkin Görüşleri” (128-149)

Merriam, Sharan B. (2013), Nitel Araştırma Desen ve Uygulama İçin Bir Rehber, S. Turan (Ed.), Ankara: Nobel Yayın.

Miles, Matthew B. ve Huberman, A. Michael (1994), Qualitative Data Analysis, Thousand Oaks, Sage.

Özbıçakçı, Fatma Ş., Çapık, Cantürk, Gördes, Nihal, Ersin, Fatma ve Kıssal, Aygül (2012), Bir Okul Toplumunda Gürültü Düzeyi Tanılaması ve Duyarlılık Eğitimi, Eğitim ve Bilim Dergisi, 37(165), 237-245.

Polat, Soner ve Buluş-Kırıkkaya, Esma (2004), Gürültünün EğitimÖğretim Ortamına Etkileri,13. Ulusal Eğitim Bilimleri Kurultayı, Malatya.

Schick, August, Klatte, Maria, ve Meis, Markus (2000), Noise Stress in Classrooms. 8. Oldenburg Symposium on Psychological Acoustics, Almanya.

Shield, Bridget ve Dockrell, Julie (2004), External and Internal Noise Surveys of London Primary Schools, Journal of the Acoustical Society of America, 114, 730-800.

Stansfeld, Stephen A.,Berglund, Britt, Clark, Charlotte, Barrio, L., Fischer, P., Öhrström, E., Heines, M. M., Head, J., Hygge, S., Van Kamp, I. ve Berry, B.F. (2005), Aircraft and road traffic noise and children's cognition and health: A cross national study, The Lancet, 365(9475), 1942-1949.

Şahin, Kemalettin, Şahin, Alattin ve Bağcı, Harun R. (2014), Sinop Şehri Yakın Çevresindeki Bazı Okullarda Gürültü Kirliliği, Studies of Ottoman Domain, 4(6), 20-31.

Şan, Bilge (2010), İlköğretim Okullarında Gürültüden Rahatsızlığın Alan Araştırması ile Belirlenmesi, İTÜ Fen Bilimleri Enstitüsü Yayımlanmamış Yüksek Lisans Tezi, İstanbul.

Tuncer, Murat, Bal, Sevil, Özüt, Aytaç ve Köse, Nihat (2012), Ortaöğretim Kurumları Öğrenme Ortamlarının Çeşitli Değiş̧kenler Açısından Değerlendirilmesi, Gaziantep Üniversitesi Sosyal Bilimler Dergisi, 11(1), 85-101.

Tüzel, Sait (2013), Sınıf İçi Gürültünün Öğrencilerin Dinlenme Sürecindeki Bilişsel Performansına Etkisi, Eğitimde Kuram ve Uygulama, 9(4), 363-378. 
Kilis 7 Aralık Üniversitesi Sosyal Bilimler Dergisi •Cilt, 10-Sayı $19 \bullet$ Haziran 2020

Yıldırım, Ali ve Şimşek, Hasan (2011), Sosyal Bilimlerde Nitel Araştırma Yöntemleri, Ankara: Seçkin Yayıncılık. 